\title{
EARLY IDAMEAN (LATE CAMBRIAN) AGNOSTOID TRILOBITES FROM THE HUSKISSON RIVER, TASMANIA
}

\author{
by J.B. Jago and A V. Brown
}

(with one text-figure and two plates)

JAGO, J.B. \& BROWN, A.V., 1992 (31:x): Early Idamean (Late Cambrian) agnostoid trilobites from the Huskisson River, Tasmania. Pap. Proc. R. Soc. Tasm. 126: 59-65. https://doi.org/10.26749/rstpp.126.59 ISSN 0080-4703. Department of Applied Geology, Gartrell School of Mining, Metallurgy and Applied Geology, University of South Australia, The Levels, SA, Australia 5095 QBJ); and Geological Survey of Tasmania, Department of Mines, PO Box 56, Rosny Park, Tasmania, Australia 7018 (AYB).

Two trilobite taxa, Agnostus (Homagnostus) sp. and Pseudagnostus (Pseudagnostus) idalis huskissonensissubsp. nov. are described from the upper part of the Huskisson Group, western Tasmania. The only trilobite previously described from this level is the early Idamean (early Late Cambrian) zone fossil Glyptagnostus reticulatus. Palaeontological and stratigraphic evidence suggests that there may be a disconformity of very late Middle Cambrian age (about Lejopyge laevigata III Zone) within the Huskisson Group, which would correspond to a postulated disconformity of similar age from the Dundas Group at Dundas.

Key Words: trilobite, agnostoid, Cambrian, Tasmania.

\section{INTRODUCTION}

The early Late Cambrian zone fossil Glyptagnostus reticulatus (Angelin) has been known from the Huskisson River area of western Tasmania for some years (Öpik 1951, Banks 1956, 1962, Blissett 1962, Jago 1974). The purpose of this paper is to describe some additional trilobite species recently found in association with $G$. reticulatus and to discuss briefly their stratigraphic significance. AVB is responsible for the stratigraphic part of this paper; JBJ is responsible for the palaeontology.

\section{STRATIGRAPHIC SETTING}

Four new locations of the Glyptagnostus reticulatus fauna were found during re-mapping of the type area of the Huskisson Group for the Corinna 1:50 000 Geological Atlas Map Sheet (Turner et al. 1991), before it was inundated by flooding to form LakePieman. The positions of three of these localities are shown in figure 1. The Huskisson Group was defined by Taylor (1954) who divided the groupinto nineteen unnamed formations. The majority of the sequence consists of volcaniclastic conglomerate beds and lenses within a laminated siltstone and mudstone sequence. Although the Huskisson Group is, in part, a biostratigraphic correlate of the Dundas Group, the dominance in most of the Huskisson Group sequence of acid to intermediate volcanic detritus indicates a different provenance from that of the Dundas Group in its type area (Brown 1986).

In general, the Huskisson Group can be divided into three parts. An upper and lower sequence dominated by conglomerate units and an intervening succession of laminated mudstone and siltstone.

The lower conglomerate dominated sequence (Units 113 of Taylor) is approximately $950 \mathrm{~m}$ thick and derived from a mixed metasedimentary and active acid to intermediate volcanic terrain (Chv \& Chm, fig. 1). The upper conglomeratic sequence (Units 15-17 and 19 of Taylor, Chc, fig. 1), of which only $200 \mathrm{~m}$ of section survive in the type area, was derived from a dominantly metasedimentary source, with minor, reworked, volcanic material. Between the two conglomeratic sequences occurs an approximately $45 \mathrm{~m}$ interval of richly fossiliferous black pyritic mudstone and siltstone with minor sandstone beds (Unit 14 of Taylor, Chm, fig. 1). The fossils described herein come from this unit. Detailed descriptions of these sequences can be found in Brown (1986).

In the Merton Hill area, to the northwest of the area under discussion, two new fossil locations were also found within the volcaniclastic part of the succession (Brown 1986). These faunas are of late Middle Cambrian age and, as only $50 \mathrm{~m}$ of section separates these horizons from the Glyptagnostus reticulatus faunas, a disconformity around the Lejopyge laevigata III Zone is suggested. On this data, the lower conglomerate sequence would correlate with the mid to late Middle Cambrian volcanic phase, which is also recorded in the Que River area, and would be, in part, a biostratigraphic correlate of the Razorback Conglomerate of the Dundas Group and be part of the lower Dundas Group of Brown (1986). On the fossil data from the original and new locations in the Huskisson River, the upper conglomerate and fossiliferous mudstone would be correlates of the Fernflow-Comet-Fernfield-Climie Formations of the Dundas Group and belong to the upper Dundas Group of Brown (1986).

As the faunas in the volcaniclastic part of the succession are of late Middle Cambrian age and only $50 \mathrm{~m}$ of section separate these horizons from the upper siliceous conglomerate-mudstone sequence with the Glyptagnostus reticulatus horizon in the lower part, the possibility of a disconformity during the Lejopyge laevigata III Zone, as suggested by Brown (1986) from evidence in the type area of the Dundas Group at Dundas, is further supported.

In addition to a resampling of the original location (just southeast of locality 1143 on fig. l) from Unit 18 of Taylor (1954), three new localities (including 1143 and 1197) were found upstream from Taylor's original location but still within Unit 18. Locality 1079 contains abundant Glyptagnostus reticulatus and sponge spicules (Clarke 1986). The faunas from locality 1143, as described herein, contain abundant Agnostus (Homagnostus) sp., and Pseudagnostus (Pseudagnostus) idalis huskissonensis subsp. nov., plus rare $G$ reticulatus as well as sponge spicules. Prior to these 


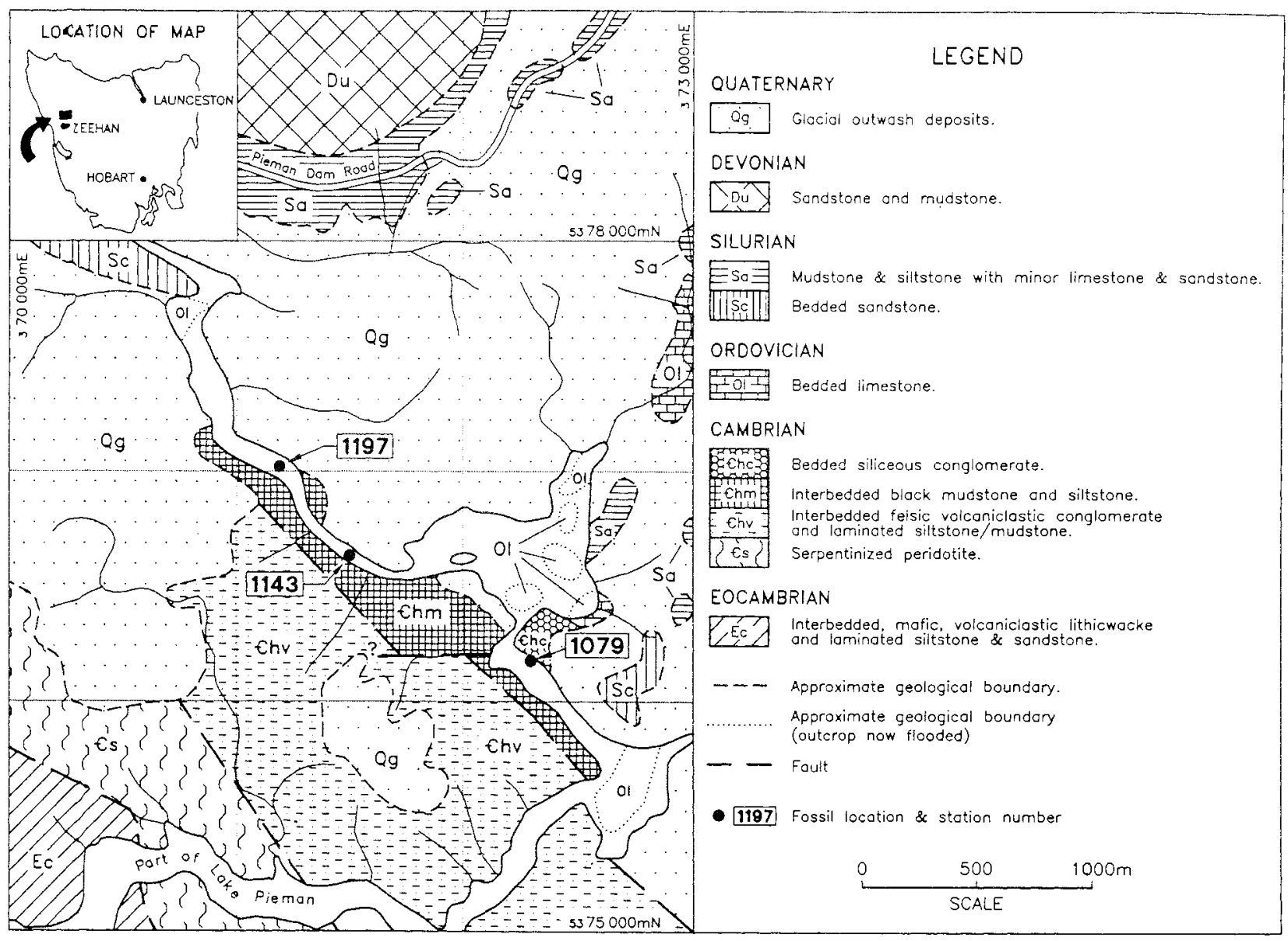

FIG. 1 - Schematic geological map with fossil locations of the Huskisson River area, western Tasmania. Modified after figure 1 of Brown (1986). All fossils described herein come from locality 1143.

discoveries, the only known trilobite from the Huskisson River faunas was $G$. reticulatus Jago (1974).

The fourth new locality (1079 on fig. I) is from within Unit 14 of Taylor, but upstream of his fossil locality, and contains abundant G. reticulatus and spicules of Protospongia sp., as well as fragments of other small agnostoids. The occurrence of this fauna substantiates the suggestion of Blissett (1962) that Unit 14 and Unit 18 of Taylor (1954) represent the same stratigraphic unit.

\section{AGE OF FAUNA}

The presence of the important zone fossil Glyptagnostus reticulatus indicates an early Idamean age. In Queensland, $G$. reticulatus is found in the basal Idamean $G$. reticulatus Assemblage Zone and in the passage from the G. reticulatus Zone up into the Proceratopyge cryptica Assemblage Zone (Shergold 1982:11). In Queensland Pseudagnostusidalis and its subspecies range throughout the Idamean (Öpik 1967 , Shergold 1982). A subspecies of P. idalis is also found in the Idamean Singing Creek Formation of southwestern Tasmania (Jago 1987). Homagnostus as defined by Shergold et al. (1990: 33) has an Idamean to immediately post-Idamean age. In view of the presence of $G$. reticulatus, the most likely age of the Huskisson River fauna is the G. reticulatus Zone on the Australian biochronological scale.

\section{TREATMENT}

All specimens from the Huskisson River locality are preserved as internal or external moulds in grey or black siltstone. For description, latex casts of the external moulds were prepared; either the latex casts or the internal moulds were then photographed after whitening with magnesium oxide. All specimens are housed in the collection of the Geological Survey of Tasmania (GST).

\section{SYSTEMATIC DESCRIPTIONS}

Family AGNOSTIDAE M'Coy, 1849

Subfamily AGNOSTINAE M'Coy, 1849

Genus Agnostus Brongniart, 1822

Subgenus Homagnostus Howell, 1935

Type species

Agnostus pisiformis Linnaeus var. obesus Belt (1867: 295, pl. 12, fig. 4a-d).

\section{Discussion}

Shergold (1982), in discussing Homagnostus Howell, 1935, treated it as a separate genus. He placed Oncagnostus Whitehouse, 1936 and Proagnostus Butts, 1926 in synonymy with Homagnostus. As noted by Shergold (1982), one of the problems in dealing with the classification of Homagnostus 
has been the poorly known type material. Rushton (in Allen etal. 1981) selected a lectotype of Homagnostus obesus and has since discussed and figured the species in more detail (Rushton 1983).

Shergold et al. (1990: 5) revised the classification of the Agnostinae and considered Homagnostus should be "reinstated as a subgenus of Agnostus, representing morphs with a laterally expanded and extended pygidial axis". This essentially reverted to the work of Westergard (1947: 4), who first suggested that Homagnostus should be considered as a subgenus of Agnostus. The concept of Shergold et al. (1990) is followed herein.

Robison (1988: 41) revived the concept of Proagnostus as a separate genus. Shergold et al. (1990: 5) considered that Oncagnostus should be regarded as a separate genus with three subgenera, viz. 0. (Oncagnostus), O. (Kumagnostus) and o. (Strictagnostus).

\section{Agnostus (Homagnostus) sp. (pl. 1A-S)}

\section{Material}

One complete specimen plus numerous, generally poorly preserved individual cephala and pygidia are available.

\section{Description}

Small cephalon about as wide as long. Narrow border; shallow, deliquiate border furrow. Deep axial furrows; welldeveloped preglabellar median furrow. Length of glabella $0.65-0.75$ that of cephalon. Shallow, transverse glabellar furrow. Glabellar anterior sharply rounded to pointed. Broadly rounded glabellar posterior. Glabellar node centrally placed on posteroglabella. Small, simple basal lobes. Acrolobes appear unconstricted, although manner of preservation makes assessment difficult.

Pygidium slightly wider than long. Moderately wide border. Deliquiate border furrow. Unconstricted acrolobes. Well-developed posterolateral spines placed just forwards of acrolobe posterior. Wide pygidial axis has length $0.7-0.8$ that of pygidium. Narrow, well-developed axial furrows. $F_{1}$ and $\mathrm{F}_{2}$ lateral axial furrows shallow but well developed. Axis narrows at $M_{2}$; slightly to well-expanded posteroaxis with broadly rounded posterior. Elongated node extends from $\mathrm{M}_{2}$ on to anterior part of posteroaxis.

\section{Morphogenesis}

The major changes during growth are shown on the pygidium, where the pygidial axis becomes relatively wider in larger specimens and there is an expansion of the posteroaxis (pl. 1K-S). A similar change was reported and illustrated for Hornagnostus obesus by Rushton (1983) .

\section{Discussion}

The small agnostoids belonging to Homagnostus from this fauna are placed tentatively into a single species. It could be argued that two species could be distinguished, with specimens such as GST15032 (pl. 1L) and GST15027 (pl. 1S), which have an expanded pygidial posteroaxis, being placed in a second species. However, for the most part it is the larger specimens which have an expanded posteroaxis and it is considered that this expansion is due to these specimens being the end members of the morphogenetic range rather than representing a second species. The two pygidia of Homagnostus alaskensis Palmer (1968: pl. 7, figs 9, 14) show a similar change, with the larger pygidium having a more expanded posteroaxis than the smaller.

Homagnostus captiosus figured in Lazarenko (1966: pl. 1, figs 13-23) also shows variation in the shape of the posteroaxis. However, with captiosus there is no regular increase in expansion of the posteroaxis as there is with Homagnostus obesus, and the Tasmanian form, although the smallest pygidium of captiosus figured by Lazarenko (1966: pl. 1, fig. 22), has the most parallel-sided pygidial axis of the pygidia figured by Lazarenko.

The Tasmanian species has some similarities to Homagnostus obesus (Belt) as figured in Rushton (1983), although the pygidial axis extends further to the posterior than in most of the Tasmanian specimens. In the larger Tasmanian pygidia, the posteroaxis is more expanded than in obesus. The posterolateral spines of obesus are placed further forward than in the Tasmanian species.

The species described by Shergold (1982) as Homagnostus sp.l and $H$. sp. 2 also show similarities to the Tasmanian species. The pygidial axis of $H$. sp.l is more parallel-sided and extends further to the posterior than those of the Tasmanian form. Homagnostus sp. 2 of Shergold has an expanded posteroaxis, as in the larger Tasmanian specimens, although the pygidial axis of $H$. sp. 2 also extends further to the posterior. The posterolateral spines of the Huskisson River specimens are larger than those in the single pygidium of H. sp.2 as illustrated by Shergold (1982: pl. 5, fig. 12).

\section{Subfamily GLYPTAGNOSTINAE Whitehouse, 1936 \\ Genus Glyptagnostus Whitehouse, 1936}

Type Species

Glyptagnostus toreuma Whitehouse (1936: 101-103, pl. 9, figs 17-20) (= Agnostus reticulatus Angelin, 1851: 8).

\section{Glyptagnostus reticulatus reticulatus (Angelin, 1851)} (pl. 1T)

Remarks

One poorly preserved partial pygidium, GST15000a+b, of this cosmopolitan zone fossil is available. The preservation is such that no formal description or discussion is warranted. This taxon has been described and figured previously from the Huskisson River area by Jago (1974).

\section{Family DIPLAGNOSTIDAE Whitehouse, 1936 Subfamily PSEUDAGNOSTINAE Whitehouse, 1936 \\ Genus Pseudagnostus Jaekel, 1909 Subgenus Pseudagnostus Jaekel, 1909}

Type Species

Agnostus cyclopyge 'Tullberg, 1880: 26, pl. 2, fig. 15a,c. 

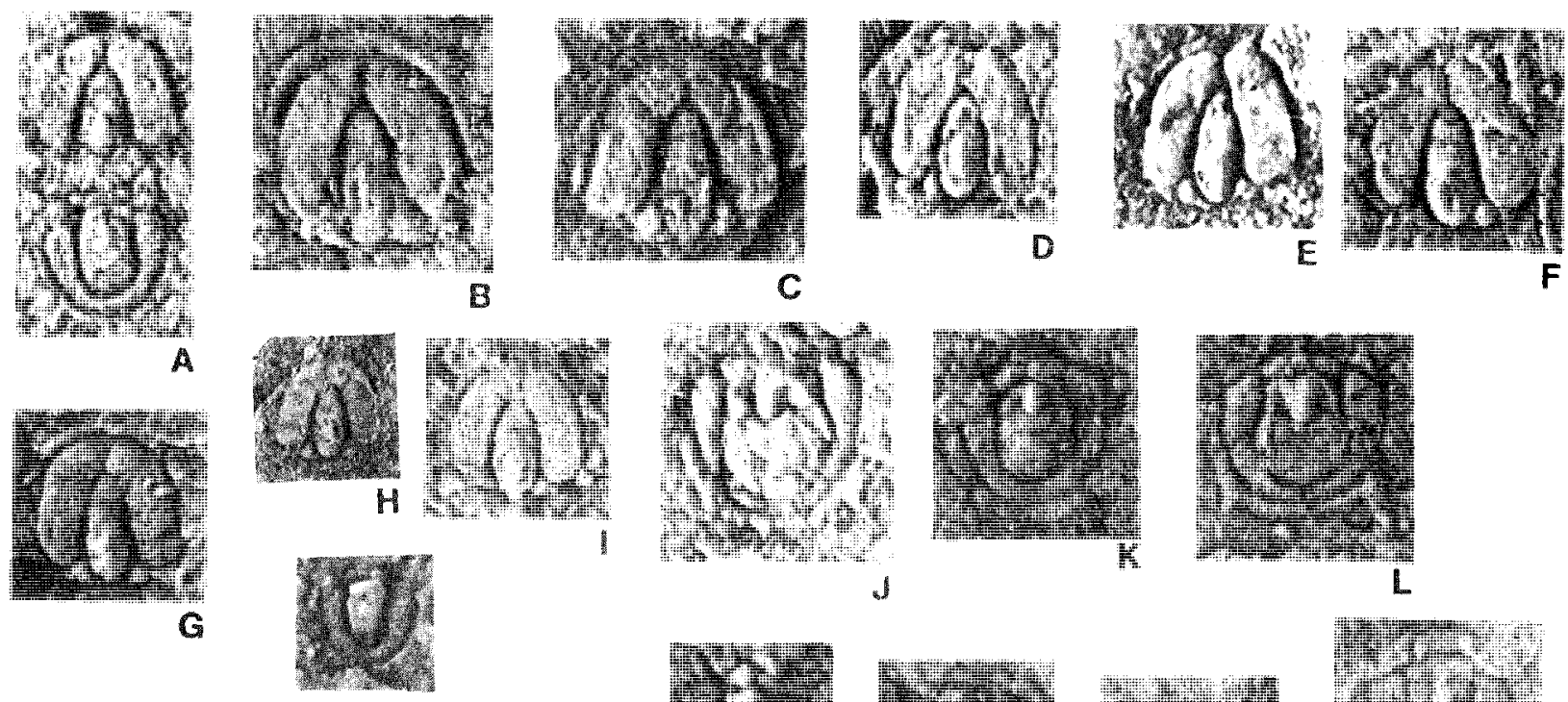
$\downarrow$

\section{L}
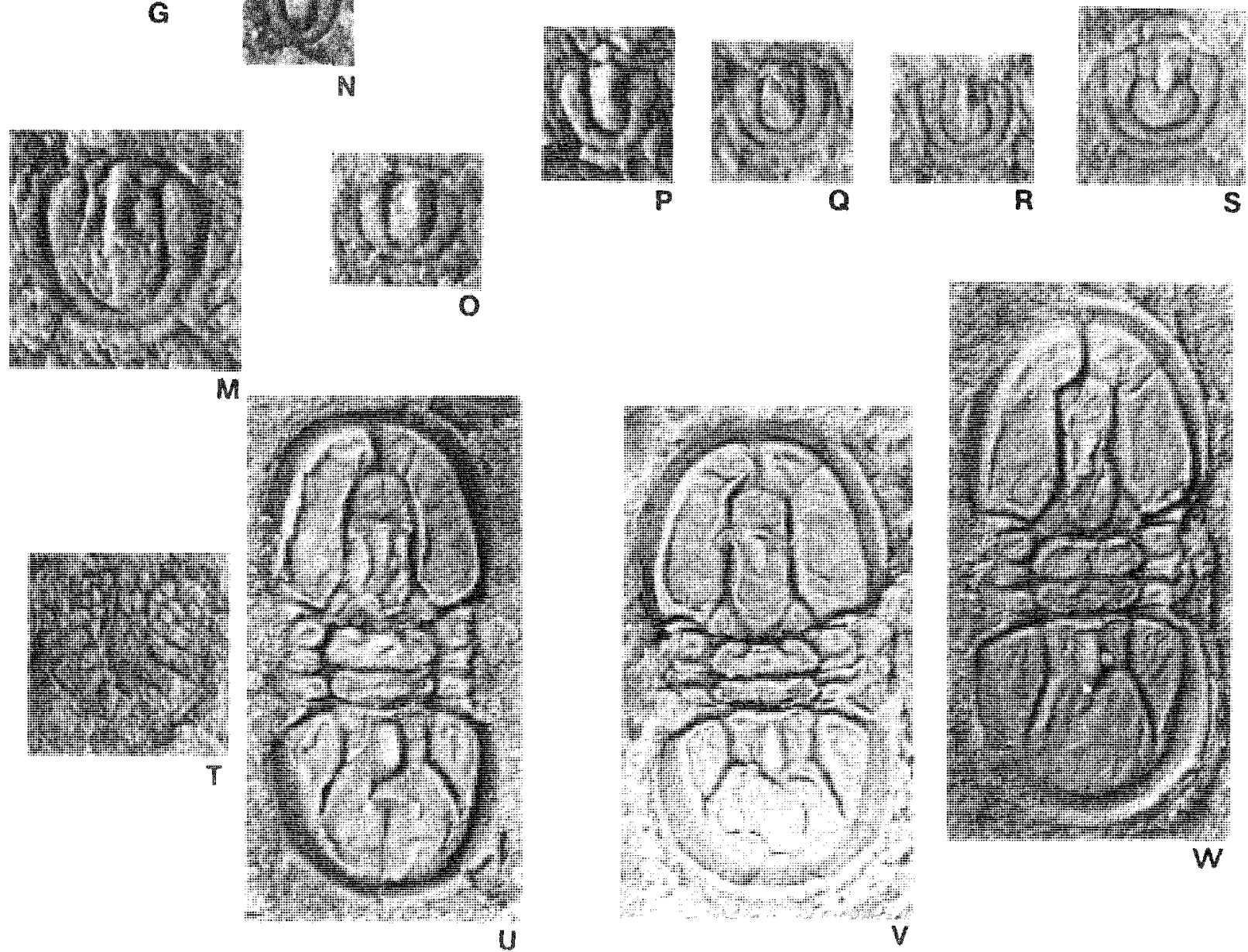

PLATE 1

(A-S) Agnostus (Homagnostus) sp. (A) GST15003, almost complete specimen, internal mould, $\times 15$. (B) GST15023, cephalon, external mould, $\times 15$. (C) GST15026, cephalon, internal mould, $\times 15$. (D) GST15025, cephalon, internal mould, $\times 10$. (E) GST15004, cephalon, internal mould, $\times 20$. (F) GST15005, cephalon, internal mould, $\times 15$. (G) GST15006, cephalon, internal mould, $\times 15$. (H) GST15029, cephalon, external mould, $\times 10$. (I) GST15021, cephalon, internal mould, $\times 14$. (J) GST15007, pygidium, internal mould, $\times 15$. (K) GST15008, pygidium, external mould, $\times 15$. (L) GST15032, pygidium, internal mould, $\times 15$. (M) GST15010, pygidium, external mould, $\times 15$. (N) GST15011, pygidium, internal mould, $\times 20$. (O) GST15009, pygidium, external mould, $\times 20$. (P) GST15012, pygidium, internal mould, $\times 20$. (Q) GST15013, pygidium, external mould, $\times 15$. (R) GST15028, pygidium, external mould, $\times 10$. (S) GST15027, pygidium, external mould, $\times 15$. (T) Glyptagnostus reticulatus reticulatus. GST75000b, pygidium, internal mould, $\times 10$.

(U-W) Pseudagnostus (Pseudagnostus) idalis huskissonensis subsp. nov. (U) GST15018, complete specimen, external mould, $\times 8$. (V) GST15022, complete specimen, internal mould, $\times 8$. (W) GST150016, complete specimen, internal mould, $\times 8$. All specimens were whitened with magnesitum oxide prior to photography. 


\section{Pseudagnostus (Pseudagnostus) idalis Öpik, 1967 Pseudagnostus (Pseudagnostus) idalis huskissonensis subsp. nov. \\ (pl. $1 \mathrm{U}-\mathrm{W}$, pl. $2 \mathrm{~A}-\mathrm{O}$ )}

\section{Diagnosis}

A subspecies of $P$. (P.) idalis with a relatively long anteroglabella, an anteriorly placed glabellar node, a pygidium with well-developed accessory furrows and short posterolateral spines placed well forward of the deuterolobe posterior.

\section{Holotype}

The almost complete specimen, GST15024 (pl. 2A), is designated as holotype.

\section{Material}

About ten complete specimens plus about twenty individual cephala and twenty individual pygidia. The individual cephala and pygidia include some immature specimens.

\section{Description}

Cephalon slightly wider than long. Narrow, slightly convex border; very wide, shallow border furrow. Constricted acrolobe length c. 0.9 that of cephalon. Well-defined preglabellar median furrow. Genae appear to be smooth, although a slight scrobiculation would not be distinguished from the effects of distortion. Parallel-sided glabella has a length c. 0.65-0.7 that of cephalon; at transverse glabellar furrow, glabella width c. $0.25-0.3$ that of cephalon. Glabella bounded by moderately deep axial furrows. Simple basal lobes linked by narrow connective band. Shallow transverse glabellar furrow curves gently rearwards. In some specimens (e.g. pl. 2B) there is a suggestion of an $\mathrm{F}_{2}$ furrow with the glabella being very slightly expanded between $F_{2}$ and the transverse glabellar furrow. Elongated glabellar node placed well forward at approximate position of $\mathrm{F}_{2}$ furrows.

Pygidium wider than long. Narrow, convex border; very wide, shallow border furrow. Narrow, elevated, strongly geniculate shoulders. Wide, shallow articulating furrow arched posteriorly; short (sag.), elevated articulating halfring. Markedly constricted acrolobe has a length c. $0.8-0.9$ that of pygidium (excluding axial half-ring).

Anteroaxis outlined by shallow axial furrows which converge very gently to $F_{2}$ furrow. $M_{2}$ slightly longer (sag.) than $M_{1}$. Prominent, elongated node on $M_{2}$ extends across $\mathrm{F}_{2}$ and on to posteroaxis. $\mathrm{F}_{1}$ furrow very shallow; $\mathrm{F}_{2}$ furrow shallow and directed inwards and very slightly to posterior from either end.

Shallow but well-defined accessory furrows; if continued across border, they would strike pygidial margin a little to posterior of posterolateral spines. Short posterolateral spines placed well forward of deuterolobe posterior. Smooth pleural areas.

The cracked nature of many of the specimens, both cephala and pygidia, suggests that the subspecies had a thin shell.

\section{Morphogenesis}

In immature cephala, such as that shown in plate $2 \mathrm{~K}$, the border furrow is narrower than in the more mature specimens. In immature pygidia (pl. $2 \mathrm{M}-\mathrm{O}$ ), the border is also narrower than in more mature specimens. The deuterolobe becomes progressively relatively larger in more mature specimens. A similar increase in deuterolobe size with growth is seen in
Pseudagnostus vastulus, as illustrated by Shergold (1982: pl. 1, figs 8-14). As in vastulus, the posterolateral spines of buskissonensis migrate forwards with growth.

\section{Discussion}

Pseudagnostus idalis huskissonensis is placed within the $P$. idalis complex, as discussed by Shergold (1982). It is somewhat difficult to compare the Huskisson River specimens with the various species of Pseudagnostus described by Öpik (1967), Henderson (1976) and Shergold (1982) from Queensland, because the Queensland specimens are preserved in limestone and retain their convexity, whereas the Huskisson River specimens are flattened and occur in shale. Nevertheless, there appear to be enough differences to justify the erection of a new subspecies. The anteroglabella of huskissonensis is larger than those of $P$. idalis idalis or $P$. i. sagittus from Queensland or that of $P$. i. denisonensis from southwestern Tasmania. However, the anteroglabella of huskissonensis is of similar size to that figured in Shergold (1982: pl. 2, fig. 14) as $P$. idalis Öpik, 1967 , sensu lato, and indeed the glabella of $P$. i. huskissonensis is indistinguishable from $P$. idalis sensu lato. However, the pygidium of $P$. idalis sensu lato figured by Shergold (1982: pl. 2, fig. 15) is much more effaced than that of huskissonensis. The glabellar node of huskissonensis is placed further forwards than that of denisonensis. but is in a similar position to that of $P$. i. idalis and $P$. i. sagittus. The cephalic border of huskissonensis is narrower than that of denisonensis. The pygidial spines of $P$. i. huskissonensis are placed further forwards than those of the other subspecies of $P$. idalis.

Pseudagnostus sp. (pl. 2P)

Remarks

One large cephalon (GST15030), in which the axial furrows fade out to the anterior and in which there is no clearly defined transverse glabellar furrow or preglabellar median furrow, may be an aberrant specimen of Pseudagnostus idalis huskissonensis. However, due to the differences noted above, it is referred to Pseudagnostus sp.

\section{ACKNOWLEDGEMENTS}

The cataloguing and forwarding of these specimens was arranged by M.J. Clarke (Geological Survey of Tasmania). This work was supported by an ARC grant to JBJ.

\section{REFERENCES}

Alien, P.M., Jackson, A.A. \& Rushton, A.W.A., 1981: The stratigraphy of the Mawddach Group in the Cambrian succession of North Wales. Proc. Yorkshire Geol. Soc. 43: 295-329.

Angeiln, N.P., 1851: Palaeontologica Suecica. Pars. 1. Iconographica crustaceorum formationis transitionis. Fasc. 1: 1-24.

BanKS, M.R., 1956: The Middle and Upper Cambrian Series (Dundas Group and its correlates) in Tasmania. In El Sistema Cambrico, su Paleogeografia y el Problema de su Base. 20th Session of the International Geological Congress, Mexico, 2: $165-212$.

Banks, M.R, 1962: The Cambrian System. J. Geol. Soc. Aust. 9: $127-145$

Bet.T, T., 1867: On some new trilobites from the upper Cambrian rocks of North Wales. Geol. Mag. 4: 294-295. 

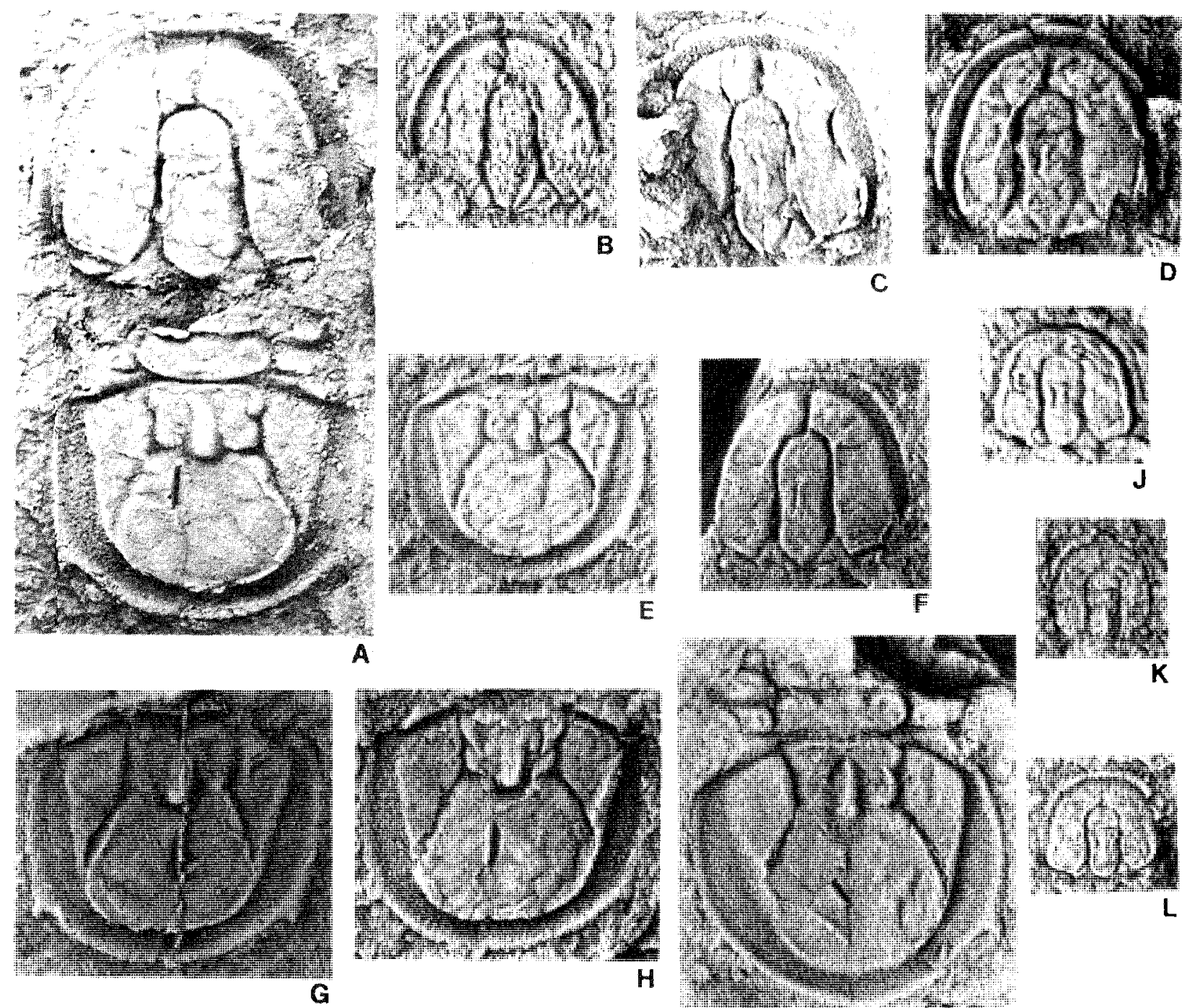

A
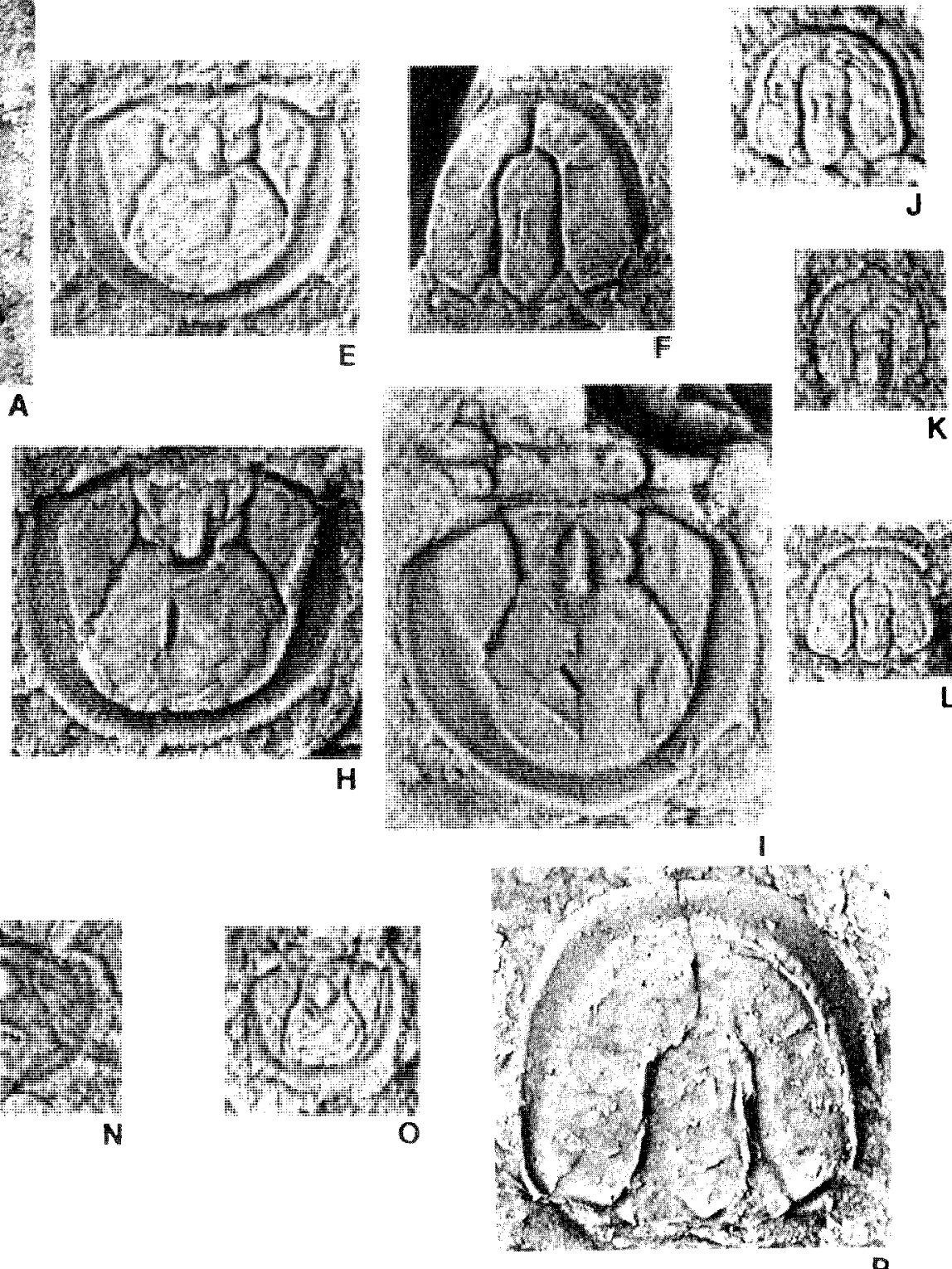

PLATE 2

(A-O) Pseudagnostus (Pseudagnostus) idalis huskissonensis subsp. nov. (A) GST15024, holotype, complete specimen, internal mould, $\times 8$. (B) GST15014, cephalon, internal mould, $\times 8$. (C) GST15020, cephalon, internal mould, $\times 8$. (D) GST15015, cephalon, external mould, $\times 8$. (E) GST15019, pygidium, internal mould, $\times 8$. (F) GST15033, cephalon, internal mould, $\times 8$. (G) GST15017, pygidium, external mould, x8. (H) GST15034, pygidium, internal mould, x8. (I) GST15031, pygidium, internal mould, $\times 8$. (J) GST15035, cephalon, internal mould, $\times 10$. (K) GST15037, cephalon, internal mould, $\times 15$. (L) GST15038, cephalon, internal mould, $\times 10$. (M) GST15039, pygidium, internal mould, $\times 15$. (N) GST15036, pygidium, internal mould, $\times 15$. (O) GST15016, pygidium, external mould, $\times 10$. (P) Pseudagnostus sp. GST15030, cephalon, external mould, $\times 8$. All specimens were whitened with magnesium oxide prior to photography. 
BursetT, A.H., 1962: Zeehan, Tasmania. Tasm. Dep. Mines 1 mile Geol. Atlas Ser. Explan. Rep., Sheet 50 (7914S).

Brown, A.V., 1986: Geology of the Dundas-Mt. Lindsay-Mt. Ramsay area. Geol. Surv. Tasm. Bull. 62.

Clarke, M.J., 1986: Late Cambrian agnostid faunas from the Huskisson River area. Geol. Sum. Tasm. Bull. 62: appendix $1,151$.

Henderson, R.A., 1976: Upper Cambrian (Idamean) trilobites from western Queensland, Australia. Palaeontology 19: 325364.

JAGO, J.B., 1974: Glyptagnostus reticulatus from the Huskisson River, Tasmania. Pap. Proc. R. Soc. Tasm. 107: 117-127.

JAGO, J.B., 1987: Idamean (Late Cambrian) trilobites from the Denison Range, sourh-west Tasmania. Palaeontology 30: 207-231.

LAZARENKO, N.P., 1966: Biostratigraphy and some new trilobites from the Upper Cambrian of the Olenek Uplift and Karaulakh Mountains. Uchenye Zapiski, Paleontologiya i Biostratigrafiya 11: 33-78. [In Russian.]

ÖpIK, A.A., 1951: Discovery of fossiliferous Upper Cambrian in Tasmania. Bur. Miner. Resour., Geol. Geophys. Aust. Rec. 195: $1-40$.

ÖPIK, A.A., 1967: The Mindyallan fauna of north-western Queensland Bur. Miner. Resour., Geol. Geophys. Aust. Bull. 74(1): 404 pp; 74(2): $167 \mathrm{pp.}$

PaLmer, A.R., 1968: Cambrian trilobites of East-Central Alaska. US Geol. Sum. Prof. Pap. 559-B: 1-105.
Robison, R.A., 1988: Trilobites of the Holm Dal Formation (late Middle Cambrian), central North Greenland. Meddelelser om Gronland. Geoscience 20: 23-103.

Rushron, A.W.A., 1983: Trilobites from the Upper Cambrian Olenus Zone in central England. Spec. Pap. Palaeontol. 30: $107-139$.

SHergord, J.H., 1982: Idamean (Late Cambrian) trilobites, Burke River Structural Belt, Western Queensland. Bur. Miner. Resour., Geol. Geophys. Aust. Bull. 187: 1-70.

Shergold, J.H., Laurie, J.R. \& Sun, X.W., 1990: Classification and review of the trilobite order Agnostida Salter, 1864: an Australian perspective. Bur. Miner. Resour., Geol. Geophys. Aust. Rep. 296: 1-93.

TAYloR, B.L., 1954: Progress Report on the North Pieman Mineral Area. Unpubl. rep. Tasm. Dep. Mines.

Tullberg, S.A., 1880: Agnostus-artena i de Kambriska aflagringarne vid Andrarum. Sveriges Geologiska Undersökning. Avhandlingar C42:1-37. [In Swedish.]

Turner, N.J., Brown, A.V., MoCi.enaghan, M.P. \& Soetrisno, I., 1991: Corinna, Tasmania. Tasm. Dep. Mines Geol. Atlas 1:50 000 Series, Sheet $7914 \mathrm{~N}$.

WeSTERG̊̊rD, A.H., 1947: Supplementary notes on the Upper Cambrian trilobires of Sweden. Sveriges Geologiska Undersökning. Avhandlingar C489: 1-35.

Whitehouse, F.W., 1936: The Cambrian faunas of north-eastern Australia. Parts 1 and 2. Mern. QLd Mus. 11: 59-1 12.

(accepted 6 December 1991) 